\title{
Osoba ludzka w doświadczeniu mistyków Karmelu
}

Teologia duchowości zajmuje się człowiekiem powołanym do świętości i mistycznego zjednoczeniem z Bogiem, a co za tym idzie, będącym w nieustannej relacji: z Bogiem, z drugim człowiekiem, z rzeczywistością stworzoną, którą stanowi także on sam.

Przez doświadczenie mistyków Karmelu będziemy tu rozumieć nie jakieś pojedyncze nadzwyczajne wydarzenia, ale Bożą mądrość, jaką zdobyli oni w całym swoim życiu.

Temat wskazuje także na źródła, którymi są dzieła mistyków Karmelu. W tym referacie ograniczymy się do trzech z nich doktorów Kościoła powszechnego: św. Jana od Krzyża, św. Teresy od Jezusa i św. Teresy od Dzieciątka Jezus.

Karmelitańscy mistycy, pouczając o procesie zjednoczenia człowieka z Bogiem, wskazują na wspaniałość człowieka odkupionego, będącego w stanie łaski uświęcającej, i na jego godność, ale także zmuszeni są sięgać do antropologii teologicznej, by wyjaśnić określone mechanizmy działające w człowieku i dynamikę tego procesu. W ten sposób wyłaniają się trzy zasadnicze bloki tematyczne: godność osoby ludzkiej, antropologia mistyczna oraz człowiek w procesie mistycznego zjednoczenia z Bogiem. 


\section{Godność osoby ludzkiej w doświadczeniu mistyków}

Karmelitańscy doktorzy nie znali współczesnej nauki Kościoła o godności ludzkiej osoby. Znali jednak przekaz biblijny i otrzymali jego mistyczne zrozumienie. Wielkie zasługi na tym polu posiada św. Teresa z Ávili, w szczególności w odniesieniu do godności kobiety. Nie należy się dziwić, że ludzie, którzy tak bardzo zbliżyli się do Boga, jednocześnie doskonale zrozumieli, kim jest człowiek. Wszyscy mistycy, niezależnie od typowych problemów epoki, rozumieli problem godności człowieka z tej racji, że byli w bliskim kontakcie z Bogiem, który jest jej źródłem. Jak nikt inny święci rozumieli ten związek Stwórcy i stworzenia. Bez tego elementarnego i źródłowego dla człowieka odniesienia nie jest możliwa ani świętość, ani właściwe rozumienie sensu ludzkiego życia. Odniesienie człowieka do Boga jest krokiem absolutnie podstawowym w kwestii godności osoby.

Teresa rodzi się i wzrasta w środowisku kulturowym, które nie sprzyja integralnej formacji kobiety. Dotyczy to środowiska tak świeckiego, jak i religijnego. O kobietach mówiono, że to słaba płeć, że brak im wykształcenia, mają skłonność do „nawiedzeń", są niestałe, niezdolne do pełnienia funkcji publicznych, wymagają opieki fizycznej i psychicznej, etc. Taki jest typowy dla czasów świętej mistyczki obraz kobiety ${ }^{1}$.

Jaka będzie reakcja Teresy na tę niesprzyjającą kobietom mentalność kulturalną i religijną ówczesnego świata? Prawdopodobnie nie była w stanie obiektywnie jej ocenić. Zdaje się bowiem zgadzać z wieloma krążącymi opiniami o mniejszej wartości kobiety. Wielokrotnie nawet nie używa słowa „kobieta”, ale zdrobniale „kobiecina”, by jeszcze bardziej podkreślić tę małość i słabość, np. „Dla kobieciny, jaką ja jestem, słabej i małego

1 M.M. Banbridge, Mujer/es, w: Diccionario de Santa Teresa de Jesus, red.

T. Alvares, Burgos 2001, s. 1010-1019. 
ducha” (Ż 11,14)2; "grzesznej, słabej, bojaźliwej kobiecinie..." (Ż 28,18). W Sprawozdaniach wyznaje, że przez sześć lat wystawiano ją na ciężkie próby, nie wierząc w działanie łaski w niej, po czym dodaje, że nawet nie wyznawała tego przed spowiednikiem z obawy, że zostanie wyśmiana, a cała rzecz uznana „za czcze mrzonki kobiece" (S 4,5) ${ }^{3}$.

Uwzględniając charakter nauczania św. Teresy i sytuację historyczną, w jakiej się ona znajdowała, można się domyślać, że termin „godność” nie będzie pojawiać się w jej pismach zbyt często. Jednak to, co znajdujemy w bardzo precyzyjnych terezjańskich konkordancjach, mimo wszystko zaskakuje. Określenie "godność" (dignidad) pojawia się we wszystkich jej pismach szesnaście razy, a pochodny termin "godny” (digno) - piętnaście razy ${ }^{4}$. Byłoby to i tak dużo, gdyby nie fakt, że wyrażenia te prawie nigdy nie oznaczają godności, o jaką nam tutaj chodzi. Oznaczają natomiast: zaszczyt, wyróżnienie, łaskę, stan, stosowność, wielkość, dostojność, wartość i oczywiście godność we właściwym tego słowa znaczeniu. Ważne, że mimo wszystko św. Teresa zna ten termin i używa go w bardzo wymownym kontekście, mianowicie w sytuacji człowieka w stanie łaski uświęcającej. Do tego powołuje się na Księgę Rodzaju 12,26-27, tekst podstawowy w rozumieniu ludzkiej godności, który mówi o stworzeniu człowieka na obraz i podobieństwo Boże. Na samym początku Twierdzy wewnętrznej, gdzie święta opisuje wizję duszy stworzonej i ozdobionej Bożą łaską, pada czterokrotnie słowo "godność": w samym tytule pierwszego mieszkania dwa razy oraz w tekście obydwu pierwszych rozdziałów pierwszego mieszkania po jednym razie. Ale nawet gdyby termin nie pojawił się ani razu, nie

2 Św. Teresa od Jezusa, Księga życia, rozdział 11, paragraf 14 (dalej: Ż), w: taż, Dzieła, t. 1, z hiszp. przeł. ks. bp H. Kossowski, Kraków $1987^{3}$.

3 Taż, Sprawozdania duchowe, nr 4, paragraf 5 (dalej: S), w: taż, Dzieła, t. 3, z hiszp. przeł. ks. bp H. Kossowski, wyd. 3, Kraków 1995, s. 7-91.

4 Concordancias de los escritos de Santa Teresa de Jesus, t. I: A-L, Roma 2000, s. 814. 
przeszkodziłoby to nam w niczym rozwijać nasz temat. Liczy się nie samo słowo, ale rzeczywistość, która za nim się kryje.

Doświadczenie mistyczne Teresy, z którego czerpie swoją wiedzę, doskonale harmonizuje ze Słowem Objawionym. W kwestii godności człowieka słyszymy od niej trzy biblijne prawdy ${ }^{5}$. 1) W zamku duszy jest wiele mieszkań na podobieństwo nieba (por. J 14,2). Już w Drodze doskonałości Teresa stwierdza, że niebo jest tam, gdzie Bóg, a dusza człowieka jest niebem Boga (por. D 28,2) ${ }^{6}$ 2) dusza sprawiedliwego jest rajem, w którym Boża Mądrość z radością przebywa (por. Prz 8,31; zob. też np. Ż 14,10); 3) wreszcie tekst, który najbardziej nas interesuje, mówiący o stworzeniu człowieka na obraz i podobieństwo Boga (por. $\mathrm{Rdz}$ 1,26-27). Teresa nawiązuje do niego w Twierdzy wewnętrznej, ale posiada głębokie doświadczenie tej rzeczywistości, co wyraża w Sprawozdaniu duchowym (S 54).

Doświadczenie wielkiej godności duszy ludzkiej ma miejsce prawdopodobnie w roku 1575, a więc na dwa lata przed napisaniem Twierdzy wewnętrznej ${ }^{7}$. Doświadczenie jako takie miało miejsce na płaszczyźnie wiary i dotyczyło obecności Trójcy Świętej w duszy; godność osoby jawi się dopiero na fundamencie tego trynitarnego doświadczenia: „Na widok tak ogromnego Majestatu, obecnego w takim nikczemnym stworzeniu, jakim jest moja dusza, zdumienie i przerażenie mię ogarnęło, a Pan rzekł do mnie: Nie jest nikczemna, córko, twoja dusza, bo uczyniona jest na wyobrażenie moje" (S 54). Zauważmy, że godność ludzkiej duszy nie bierze się z takiego czy innego postępowania człowieka, ale ze stwórczego i zbawczego dzieła Boga.

5 Por. T. Alvarez, Guida all'interno del Castello. Lettura spirituale delle Mansioni di Teresa d'Avila, Roma 2005, s. 21-22.

6 Św. Teresa od Jezusa, Droga doskonałości, rozdział 28, paragraf 2 (dalej: D), w: taż, Dzieła, t. 2, z hiszp. przeł. ks. bp H. Kossowski, wyd. 3, Kraków 1987.

7 Taką adnotację otrzymujemy od hiszpańskiego wydawcy, por. św. Teresa od Jezusa, Dzieła, t. 3, s. 82. 
Biblijne objawienie dotyczące piękna ludzkiej duszy w stanie łaski i Bożego upodobania w przebywaniu w niej Boga zostaje przyswojone przez Teresę dzięki mistycznemu doświadczeniu i stanowi trwały element jej teologicznych przekonań. Kiedy święta przystępuje do pisania Twierdzy wewnętrznej, otrzymuje do tego Boże światło i natchnienie, by rozpocząć właśnie od piękna i wzniosłości ludzkiej duszy. Opis pierwszego mieszkania składa się z dwóch rozdziałów: jeden mówi o wspaniałości duszy, drugi o jej brzydocie spowodowanej ciężkim grzechem. Obydwa bardzo dobrze naświetlają zagadnienie ludzkiej godności: pierwszy według metody pozytywnej, drugi przez ukazanie przeciwieństwa.

W nauczaniu pozytywnym Teresa nie zatrzymuje się na statycznym potwierdzeniu ludzkiej godności. Ona zaprasza czytelnika do odkrycia wspaniałości ludzkiej duszy zamieszkiwanej przez Boga dzięki „podróży” w jej głąb przez kolejne mieszkania Twierdzy - aż do siódmego, coraz bliżej centralnej komnaty, w której przebywa Oblubieniec wraz z całym niebieskim dworem.

Teresa Wielka jest wymownym przykładem osoby walczącej o godność kobiety nawet z wysokimi władzami kościelnymi. Jej siłę stanowi mistyczne doświadczenie Boga, dzięki któremu odkrywa źródło godności osoby, niezależnie od płci. Potwierdza tym samym prawdę Objawienia o ludzkiej godności, ale także pokazuje, z jaką determinacją należy walczyć o prawdę, nie zważając na wygodne wielowiekowe przyzwyczajenia społeczeństwa.

Święty Jan od Krzyża będzie podkreślał piękno i wspaniałość człowieka zjednoczonego z Bogiem i przemienionego przez Jego miłość, zwłaszcza tego znajdującego się u kresu duchowej drogi, o czym wspomnimy niżej. 


\section{Antropologia mistyczna}

Człowiek u św. Jana od Krzyża ${ }^{8}$ nazywany jest „duszą”. Dusza ma w tym przypadku dwa znaczenia: jest zasadą ożywiającą człowieka i całym człowiekiem. Nazywanie człowieka duszą ma też dobre strony. Dusza jest rodzaju żeńskiego, a to bardzo pasuje do oblubieńczego charakteru procesu zjednoczenia z Bogiem. Chrystus jest Oblubieńcem, a człowiek jest oblubienicą. Dusza jest synonimem tak mężczyzny, jak i kobiety - to po prostu człowiek jako oblubienica Chrystusa. Jan od Krzyża raz mówi o części duchowej człowieka, innym zaś razem - o całym człowieku. Trzeba śledzić kontekst. Nie musi się nam to podobać.

Najbardziej chyba zraża czytelnika rozebranie człowieka na części pierwsze: ciało, zmysły, dusza, duch, część niższa, część wyższa, pragnienia, pożądania, uczucia. Jest to zagadnienie bardzo utrudniające lekturę pism mistyków, nużące, a nawet zniechęcające do wgłębiania się w przekaz, jednak nieodzowne dla naświetlenia istotnych procesów wewnętrznej przemiany, jakie muszą się dokonać w człowieku dążącym do zjednoczenia z Bogiem. Dzisiaj panuje zupełnie inna mentalność w tym względzie. Mówimy o holistycznej wizji człowieka, chcemy traktować go całościowo, jakkolwiek nadal potrzebujemy właściwej antropologii. Jan od Krzyża myśli podobnie. Odnajdujemy u niego wizję całościową, najczęściej zawartą w pojęciu „dusza”, a także szczegółowe podziały ludzkiego bytu według klasyfikacji scholastycznej. Wszystko jest potrzebne. Jakkolwiek to słownictwo może się nam nie podobać, bez problemu możemy je przekroczyć i zrozumieć, o co naszemu mistrzowi chodzi. Chce on wyjaśnić, co dokładnie dzieje się w człowieku, gdy Duch Święty jako Boży ogień pragnie wypalić korzeń złych skłonności, trudno to pokazać bez szczegółowej antropologii.

8 Por. J.W. Gogola, Św. Jan od Krzyża dzisiaj. Doktryna sanjuanistyczna w świetle wspótczesnej duchowości, Kraków 2018, s. 48-52. 
W ślad za Objawieniem i nauką Kościoła mistycy Karmelu widzą człowieka jako głęboką jedność. Jest on po prostu kimś: mężczyzną, kobietą, dzieckiem, oblubienicą, matką, „duszą". Jednakże dydaktyczny zamiar powstających pism każe im uwzględniać różne wymiary i „części składowe” osoby ludzkiej. Najlepiej czyni to św. Jan od Krzyża, będąc jako jedyny z trzech wymienionych osób dobrze wykształcony w dziedzinie teologii i znający tradycyjne nauczanie w tej kwestii. Temat został już bardzo obszernie opracowany, więc ograniczę się do schematycznego przedstawienia istotnych rzeczy ${ }^{9}$.

„W ontycznej strukturze człowieka możemy wyróżnić trzy płaszczyzny: pierwszy poziom to sfera zmysłowa lub zwierzęca, siedlisko pożądań zmysłowych, poprzez które człowiek jest prowadzony do przedmiotów znajdujących się poza nim. Druga płaszczyzna, pośrednia, jest miejscem władz duchowych, takich jak: intelekt, pamięć i wola, poprzez które człowiek wchodzi w kontakt ze światem świadomości. Trzecią płaszczyznę, najbardziej tajemniczą i głęboką, stanowi substancja duszy, centrum bycia, gdzie mają swoje źródło władze umysłowe człowieka, miejsce, w którym Bóg komunikuje siebie duszy. Ta trzecia płaszczyzna jest tożsama z obrazem Boga, według Księgi Rodzaju, odciśniętym w człowieku"10. W tym podziale nie ma żadnej oryginalności. Hiszpański mistyk przepisuje główne jego składniki od innych albo zakłada, że są znane. Głównie w Drodze na Górę Karmel rozkłada psychikę człowieka na drobne części

9 Por. F. Ruiz Salvador, Św. Jan od Krzyża. Pisarz - pisma - nauka, tłum. J.E. Bielecki, Kraków 1998, s. 388-430; E. Pacho, S. Juan de la Cruz, Temas fundamentales, t. 1, Burgos 1984, s. 138-155; L. Boriello, Linie antropologiczne $w$ systemie doktrynalnym św. Jana od Krzyża, tłum. J. Machniak, w: Mistyczne doświadczenie Boga. 400-lecie śmierci św. Jana od Krzyża 1542-1591, red. J. Machniak, Kraków 1991, s. 21-33.

10 L. Boriello, Linie antropologiczne w systemie doktrynalnym św. Jana od Krzyża, s. 24. Cytowany tu autor powtarza ten schemat za innymi. Precyzyjny schemat psychicznej struktury człowieka można znaleźć w: S. Świerzawski, Święty Tomasz na nowo odczytany, Poznań 2002, s. 152. 
z tym zamiarem, aby ją następnie stopniowo, część po części, naprawiać; w innych dziełach nie czyni już tego, bo interesuje go inny aspekt procesu zjednoczenia ${ }^{11}$. Te trzy płaszczyzny doktor mistyczny sprowadzi do dwóch, nazywając je „zmysłami” i „duchem”. Podkreśli wielki antagonizm pomiędzy nimi, którego nie usprawiedliwia do końca nawet grzech pierworodny. Jest on po prostu przewidziany przez Stwórcę i ma swoją pozytywną rolę do spełnienia w człowieku. W długotrwałym i oczywiście bolesnym procesie duchowym dochodzi tak do pogodzenia ze sobą tych dwóch bloków, jak i do zjednoczenia całego człowieka z Bogiem. Należy unikać w tym względzie ścisłej chronologii, jakby wewnętrzna jedność w człowieku była warunkiem zjednoczenia ze Stwórcą. To właśnie pogłębiające się zjednoczenie z Bogiem skutkuje wewnętrzną integracją człowieka. Ścisłe podziały potrzebne są do uporządkowania lektury, ale nie odzwierciedlają dynamiki zjednoczenia.

Jaki jest więc sens i użyteczność tych rozróżnień? Taka antropologiczna baza jest potrzebna mistykom do wyjaśnienia złożonych procesów zachodzących w życiu duchowym człowieka. Przy lekturze pism św. Jana od Krzyża i licznych komentarzy innych autorów czytelnik może odnieść wrażenie, że bez dokładnego poznania średniowiecznej antropologii nie da się zrozumieć naszego mistrza. Poniekąd ma rację. Te podziały trzeba znać, by zrozumieć, o czym on mówi. Jednak nie powinno się stracić z pola widzenia zasadniczego motywu lektury jego dzieł. Nie czytamy go po to, by zrozumieć jego, ale po to, by samemu wzrastać w powołaniu do zjednoczenia z Bogiem. A takie podejście zmienia wiele w kwestii skomplikowanych podziałów.

11 Por. F. Ruiz Salvador, Św. Jan od Krzyża, s. 390-391. 


\section{Człowiek w procesie mistycznego zjednoczenia z Bogiem}

Tradycja duchowości przekazuje cenną wiedzę o człowieku. Można ją podzielić na trzy grupy: 1) człowiek u progu przemiany, a zatem niedojrzały, niedoskonały, wewnętrznie rozproszony, 2) człowiek wewnętrznie zintegrowany, duchowo dojrzały, 3) człowiek w drodze.

Tak czyni św. Jan od Krzyża. Karmelitański mistyk szeroko omawia mechanizmy wewnętrznego zniewolenia człowieka (zwłaszcza DGK, I) ${ }^{12}$; ukazuje piękno człowieka wolnego na końcu procesu wewnętrznej przemiany (dalsze strofy $\mathrm{PD}^{13} \mathrm{z}$ ich komentarzem i oczywiście ŻPM) $)^{14}$ oraz cały proces przechodzenia od niewoli do wolności, od miłości egoistycznej do bezinteresownej i wolnej, od niewiedzy do mądrości (zwłaszcza obydwie księgi NC $)^{15}$.

\subsection{Człowiek na poczq̨tku duchowej drogi}

Wstępne zjednoczenie i duchowy zapat. Przez początek duchowej drogi, a co za tym idzie duchowej przemiany rozumie się taki stan człowieka, w którym ten w sposób w pełni świadomy dzięki właściwej chrześcijańskiej formacji podejmuje współpracę z łaską powołania do zjednoczenia z Bogiem ${ }^{16}$. Taki etap nazywany

12 Św. Jan od Krzyża, Droga na Górę Karmel, księga I (dalej: DGK), w: tenże, Dzieła, z hiszp. przeł. o. B. Smyrak OCD, Kraków 1986.

13 Tenże, Pieśń duchowa (dalej: PD; kolejne cyfry oznaczają numer strofy oraz paragraf), w: tenże, Dzieła.

14 Tenże, Żywy płomień miłości (dalej: ŻPM; kolejne cyfry oznaczają numer strofy oraz paragraf), w: tenże, Dzieła.

15 Tenże, Noc ciemna (dalej: NC; następująca cyfra rzymska oznacza księgę, natomiast cyfry arabskie rozdział i paragraf), w: tenże, Dzieła.

16 Por. J.W. Gogola, Teologia komunii z Bogiem. Synteza teologii duchowości, wyd. 4, Kraków 2012, s. 113-118. 
jest duchowym nawróceniem. W klasyce chrześcijańskiej duchowości, mam na myśli podręczniki i traktaty, ale również naukę wielkich mistrzów, cały proces uświęcenia omawiano, począwszy od tego właśnie momentu.

Siłą napędową procesu zjednoczenia nie jest ludzki wysiłek (umartwienie, szeroko pojęta asceza), ale uprzedzająca łaska, a takie wrażenie mniej wtajemniczony czytelnik mógłby odnieść po lekturze Drogi na Górę Karmel. Doktor mistyczny w wymowny sposób mówi o nim w założeniu Pieśni duchowej. Człowiek, który zostaje zraniony Bożą miłością, jednocześnie rozumie, że uczyniła to uprzedzająca działalność Boga, i na podobieństwo doświadczenia św. Pawła pod Damaszkiem oddaje się całkowicie Bogu, niejako mówi fiat Jego zbawczemu planowi. Najwymowniejszy w tym względzie jest opis wielkiego zapału i porywu miłości „duszy” zakochanej w Umiłowanym, którym jest Chrystus, w komentarzu do pierwszej strofy Pieśni duchowej: „W pierwszej strofie dusza zakochana w Słowie, Synu Bożym swym Oblubieńcu, pragnie złączyć się z Nim poprzez jasne i istotowe widzenie, wyraża swe miłosne pragnienia i żali się Mu z powodu Jego nieobecności, tym bardziej, iż zraniona Jego miłością, dzięki której wyszła poza wszystkie rzeczy stworzone i poza siebie samą, nadal musi cierpieć z powodu nieobecności swego Umiłowanego" (PD 1,2).

W tym opisie hiszpański mistyk skupia się niemal wyłącznie na przyczynie podjęcia trudu opuszczenia wszystkiego, zaparcia się siebie i pójścia za Chrystusem. Tą przyczyną jest doświadczenie potężnej miłości Umiłowanego. W dalszej części komentarza będzie wprost mówił o ranie miłości (por. PD 1,17), o której św. Teresa z Ávili pisze dopiero w piątym mieszkaniu Twierdzy wewnętrznej, a więc umieszcza ją już na wyżynach życia mistycznego. Wyjaśnia w sposób jasny cel takich Boskich działań, „nawiedzin” duszy. „Tu Bóg przychodzi po to, aby raczej ranić niż leczyć, raczej aby ranę jątrzyć, niż przynosić ukojenie, albowiem odwiedziny te służyć mają ożywieniu i pogłębieniu pragnienia, a w konsekwencji, bólu i chęci ujrzenia Boga" (PD 1,19). 
Na podstawie tych i podobnych twierdzeń wysuwamy wniosek o możliwości kilku początków w życiu duchowym, a w każdym wypadku powoduje go bardziej lub mniej intensywne przeżycie Bożej miłości, które skłania do podjęcia trudu zjednoczenia z Bogiem. W pierwszej połowie XX wieku Reginald Garrigou-Lagrange napisał książeczkę z dziedziny życia duchowego o trzech nawróceniach i trzech drogach ${ }^{17}$. Czerpał on swoją wiedzą duchową przede wszystkim od mistrzów Karmelu. Jednak najbardziej liczy się ten ostateczny zryw i „determinacja” (św. Teresa od Jezusa) pójścia drogą ewangelicznego powołania. Dopiero rozpalonej miłością duszy Jan od Krzyża wskazuje drogę poszukiwania Chrystusa: „Słowo, Syn Boży, wraz z Ojcem i Duchem Świętym jest istotowo i osobiście ukryty w najbardziej intymnym jestestwie duszy" (PD 1,6).

Duchowy stan człowieka na początku drogi. Jan od Krzyża mówi do człowieka takiego, jak go ukazuje Objawienie: upadłego, grzesznika, prochu ożywionego przez Bożego Ducha, a jednocześnie posiadającego godność dziecka Bożego, powołanego do wzniosłego zjednoczenia z Bogiem-Trójcą Przenajświętszą poprzez zanurzenie w misterium Chrystusa - misterium śmierci i zmartwychwstania. W Synu Bożym dokonuje się tajemnica przemiany człowieka z cielesnego i ziemskiego, zdominowanego przez „zmysły”, w człowieka nowego, działającego „na sposób boski". To wszystko za cenę oczyszczającego cierpienia w mistrzowski sposób opisanego przez hiszpańskiego mistyka w księdze Nocy ciemnej.

Kiedy jednak czytamy te pesymistycznie brzmiące stronice, należy pamiętać, że chodzi o tego samego człowieka zakochanego w Bogu, o którym wspomniano wyżej. Dla zrozumienia i usprawiedliwienia potrzeby przejścia przez „oczyszczający ogień" mistycznej kontemplacji karmelitański mistyk szkicuje duchowy

17 R. Garrigou-Lagrange, Trzy nawrócenia i trzy drogi, Poznań 1934. 
obraz człowieka u początku drogi. Czyni to w sześciu rozdziałach pierwszej księgi Nocy ciemnej (por. NC I 2-7). Omawia tam ukryte korzenie siedmiu głównych wad. Daje przez to do zrozumienia, że żaden ludzki wysiłek nie wystarczy do ich usunięcia. Musi to uczynić Duch Święty specjalnym działaniem: „Chociażby początkujący najmocniej, jak potrafi, ćwiczył się w umartwieniu wszystkich swoich czynów i namiętności, nie zdoła ich pokonać całkowicie, dopóki sam Bóg nie dokona tego w duszy sposobem biernym przez oczyszczenie w tej nocy” (NC I,7,5). „Ona sama nie mogłaby w nią wejść, bo sama z siebie nie może uwolnić się od wszystkich pożądań, by dojść do Boga" (DGK I 1,5).

Jest to tym samym przestroga kierowana do duchowych przewodników, którzy całą uwagę penitenta kierują na ludzki wysiłek i w nim pokładają całą nadzieję poprawy (por. DGK I, prolog, 4-5).

\subsection{Człowiek u kresu duchowej drogi, „doskonaty”}

Wyrażenie „doskonały” celowo daję w cudzysłowie, gdyż ludzka doskonałość jest zawsze w trakcie ewolucji, nie jest nigdy ukończona; chyba że spojrzymy na człowieka z punktu widzenia czysto naturalnego i do tego w jakimś konkretnym aspekcie ludzkiej egzystencji, jednak nasza perspektywa jest inna, teologiczna.

Opierając się na nauce karmelitańskich mistrzów, można wskazać na trzy główne dziedziny przemiany: poznanie, miłość i wolność. W tym miejscu trzeba zadowolić się jedynie schematycznym ujęciem.

Miłość. Cały proces duchowej przemiany służy całkowitemu wyzwoleniu człowieka z niewoli grzechu i uzdolnieniu do miłowania „na sposób boski”. Dlatego droga przez noc, która jest jednocześnie drogą zjednoczenia z Bogiem, prowadzi tym samym do wolności i wypełnienia najważniejszego przykazania miłości Boga i bliźniego (por. NC II 11,4). Człowiek wewnętrznie prze- 
mieniony niejako promieniuje Bogiem Miłością, co przejawia się w całym sposobie jego bycia i działania.

U św. Teresy z Ávili raczej nie znajdziemy oryginalnej nauki na temat miłości Boga i bliźniego. Potwierdza ona to, co od wieków wiadomo. Przez zjednoczenie z Bogiem człowiek staje się do Niego coraz bardziej podobny w sposobie miłowania. Także ludzka miłość coraz bardziej staje się bezinteresowna, darmowa, wolna i powszechna. Płeć nie ma tu zupełnie znaczenia.

Wolność. Osiągnięcie pełnej wolności w miłowaniu Boga ponad wszystko Jan od Krzyża przypisuje działaniu kontemplacji wlanej ${ }^{18}$. Wyrażenie może nas nieco mylić, gdyż w popularnym rozumieniu tego słowa, zgodnym zresztą z jego etymologią (gr. theorein), oznacza po prostu patrzenie, wpatrywanie się w coś $\mathrm{z}$ uwagą. Tymczasem u naszego doktora ten jej aspekt w księgach Drogi na Górę Karmel i Nocy ciemnej jest praktycznie pomijany. W naturze kontemplacji mistycznej, wlanej, wyeksponowane jest natomiast działanie Boga.

U źródła wszelkiej duchowej przemiany wierzącego znajdującego się w nocy ciemnej znajduje się ukryte działanie Ducha Świętego, z czego człowiek może nie zdawać sobie sprawy w momencie, gdy akt ten się dokonuje. Podczas biernej nocy Duch Święty doprowadza człowieka do wzniosłej miłości, do mądrości miłości i tym samym do wolności wewnętrznej. Tylko pobieżnie spojrzymy na obraz człowieka wolnego po przejściu przez noc bierną, by mieć ideę, co w nim wymaga przemiany i w jakim kierunku ona zmierza. Ograniczymy się tu do trzech doniesień wolności: w stosunku do zła, do stworzeń i w stosunku do siebie samego.

Wolność od zła. Oto bardzo wymowny tekst obrazujący ten skutek: „Dusza podniesiona do tego stanu jest do pewnego stopnia taka, jakim był Adam w stanie niewinności, w którym nie wie-

${ }_{18}$ Por. J.W. Gogola, Św. Jan od Krzyża dzisiaj, s. 166n. 
dział, co to jest zło, ponieważ jest ona tak niewinna, że nie pojmuje zła i nie sądzi źle o niczym. Mogłaby słyszeć albo widzieć na własne oczy rzeczy złe, a nie rozumiałaby, że są złe istotnie. Nie ma bowiem już w niej skłonności do złego, na podstawie której mogłaby je osądzić, gdyż Bóg wykorzenił w niej skłonności niedoskonałe i ignorancję, przez doskonały stan prawdziwej wiedzy" (PD 26,14).

Jedną z cech wolności jest równość. Równość dotyczy miłości, zatem jesteśmy podobni do Boga w miłowaniu. Dusza staje się Bogiem przez uczestnictwo. „Tutaj, mając już miłość doskonałą, dusza nazywa się oblubienicą Syna Bożego. Ta nazwa oznacza zrównanie się jej z Nim i w tym zrównaniu przyjaźni wszystkie rzeczy są im wspólne" (PD 28,1). Taki jest plan od samego początku Boga względem człowieka: włączyć go w swoje życie, we wspólnotę z sobą, by wszystko było wspólne. Do tego zmierza ukryte Boże działanie przez kontemplację wlaną.

Wolność w stosunku do stworzenia. Człowiek wewnętrznie przemieniony zaczyna inaczej niż przedtem patrzeć na stworzenie. Wszystko, co Bóg stworzył, było bardzo dobre i to się nie zmieniło. Zmieniła się relacja. Człowiek wewnętrznie nieuporządkowany chce się niejako nasycić bogactwem stworzenia, chce nasycić swój głód pożądań. Człowiek duchowy patrzy na nie okiem czystym, nieegoistycznym. A że jest jedno z Bogiem, może wyśpiewywać: „Moje są niebiosa i moja jest ziemia”, moje jest wszystko. Wszyscy mistycy byli wielkimi kontemplatykami także natury. To nie jest jeszcze nic nadzwyczajnego. Wszyscy potrafimy to zrozumieć, ale ciekawe jest zagadnienie omówione w kolejnym punkcie.

Wolność $w$ stosunku do siebie. Człowiek oczyszczony potrafi się cieszyć własną prawdą. Niektórzy mistycy wyznają, że w pewnym momencie zachwycili się własną pięknością. Ujrzeli się obrazem Boga. Piękno dzieła stwórczego i zbawczego dostrzegli 
zrealizowane w sobie. Oto dwa przykłady z pism naszego mistrza: „Gdy więc oblubienica ma w swej duszy cnoty w stopniu doskonałym i raduje się zwykłym pokojem w nawiedzeniach, jakimi ją zaszczyca Umiłowany, oprócz tego w niektórych chwilach raduje się w najwyższym stopniu ich słodyczą i wonnością, a to z powodu dotknięcia, jakie sprawia w nich Umiłowany, podobnie jak odczuwa się piękno i zapach lilii oraz innych kwiatów, gdy są poruszone i mają otwarte kielichy... Wtedy to pełna przedziwnej rozkoszy i smaku miłości łączy je wszystkie razem i składa Umiłowanemu jako bukiet przecudnych kwiatów" (PD 16,1).

Kolejny tekst jest jeszcze bardziej niecodzienny. Święty, komentując werset poematu „Chodźmy przejrzeć się w Twojej piękności”, pisze: „Abym do tego stopnia została przemieniona w Twą piękność, byśmy będąc upodobnieni w piękności, mogli sami się przeglądać w Twojej piękności, posiadając już tę samą Twoją piękność. Do tego stopnia, że gdy spoglądać będziemy na siebie, ujrzymy w sobie piękność każdego z nas, bo obie piękności są tylko Twoją pięknością, gdyż ja pochłonięta zostałam w Twojej piękności” (PD 36,5).

Przeciętnemu wierzącemu pewno nie przyszłoby nawet do głowy, że można w taki sposób mówić o sobie. Uznałby to za przejaw co najmniej braku pokory. Tymczasem człowiek wewnętrznie wolny może tak mówić.

Poznanie. Święty Jan od Krzyża nazywa kontemplację mistyczną m.in. „mądrością miłości”. Święta Teresa z Ávili także łączy nadprzyrodzone poznanie z miłością. Szczególnego rodzaju poznanie, jakie człowiek zdobywa na drodze zjednoczenia mistycznego, otrzyma nazwę „teologii mistycznej”"19.

19 Treść „teologii mistycznej” została szczegółowo przebadana i opublikowana na innym miejscu: tenże, „Teologia mistyczna” świętej Teresy od Jezusa, w: Święta Teresa od Jezusa mistrzyniq życia duchowego, red. tenże, Kraków 2002 (Karmel żywy, 3), s. 63-80. 
Interesuje nas najistotniejszy przedmiot poznania, jakim jest Bóg i człowiek. Obie te dziedziny są uzależnione od siebie; bardziej jednak poznanie człowieka uzależnione jest od poznania Boga niż odwrotnie.

„Wielka to zaiste wina nasza i wstyd, że z własnej winy naszej nie znamy samych siebie ani nie wiemy, czym jesteśmy" (TW I 1,2$)^{20}$. Jest to jeszcze większy wstyd niż ten, gdybyśmy nie wiedzieli, czyim jesteśmy dzieckiem i z jakiego kraju pochodzimy - rozumuje dalej św. Teresa. Wielu zadowala się ogólną wiedzą o tym, że człowiek ma duszę nieśmiertelną; nie przeczuwa jednak jej wspaniałości, pojemności i piękna (por. TW I, 1, 2). Bez znajomości piękna duszy, a przede wszystkim bez świadomości, że zamieszkuje w niej Chrystus, człowiek nie będzie się starał, by była ona piękna. Święta Teresa jasno rozróżnia piękno ofiarowane przez Boga i piękno zdobywane własnym wysiłkiem. Tak samo rozróżnia poznanie zdobywane przez studium, naukę, i poznanie wlane, udzielane przez Boga. Mistyczne poznanie posiada swoje charakterystyczne cechy oraz treść ${ }^{21}$. Jego cechy to: poznanie o charakterze biernym, poznanie proste, poznanie smakowite, poznanie ciemne, poznanie intuicyjne, bezpośrednie, poznanie niewyrażalne w słowach; natomiast treść to: eksploracja własnego świata wewnętrznego, tj. duszy, Chrystus i Jego święte człowieczeństwo, Bóg jako rzeczywistość obecna dla mistyka, misterium Trójcy Przenajświętszej, Bóg jako najczystsza Prawda i źródło wszelkiej prawdy, słowo Boże, Kościół, królestwo Boże: Kościół ziemski, Kościół niebieski, misterium grzechu: grzech, szatan, piekło, misterium łaski ${ }^{22}$.

20 Św. Teresa od Jezusa, Twierdza wewnętrzna, mieszkanie 1, rozdział 1, paragraf 2 (dalej TW), w: taż, Dzieła, t. 2.

21 Por. J.W. Gogola, Teologia mistyczna św. Teresy od Jezusa, s. 63-80.

${ }^{22}$ Zob. J. Lopez-Gay, Mystique: I. Le phénomèn mystique, w: Dictionaire Spirituelle d'Ascetique et Mystique, t. 10 [1980], kol. 1895-1899. 


\subsection{Człowiek $w$ drodze do swojej pełni}

Człowiek nie od razu może osiągnąć swoją pełnię. Potrzebuje na to całego życia. Wszyscy mistrzowie życia duchowego zajmują się tą drogą: jej etapami, szczególnymi momentami, wymiarami. Święty Jan od Krzyża pisze Drogę na Górę Karmel, którą objaśnia we wszystkich swoich dziełach; św. Teresa z Ávili tworzy Droge doskonałości, o której także mówi w pozostałych swoich dziełach, a św. Teresa z Lisieux odkrywa po latach zmagania swoją „małą drogę, zupełnie nową".

Droga Teresy Wielkiej prowadzi do Boga przez własne wnętrze. Według jej koncepcji, zrozumianej dzięki Bożemu natchnieniu, wiedzie ona przez szereg mieszkań aż do centrum duszy, gdzie ma miejsce spotkanie z Bogiem (por. TW I 1,1)23. Święta pokazuje, jak postęp w modlitwie czy - inaczej mówiąc - w zjednoczeniu z Bogiem zależy od stopnia poznania Jego i siebie oraz stopnia miłości człowieka. Trzeba jednak zauważyć, że źródłem coraz głębszego poznania i coraz większej miłości jest Duch Święty. Często w dawnej ikonografii na obrazach św. Teresy widnieje Jego symbol - gołębica.

Święty Jan od Krzyża całą koncepcję drogi oczyszczenia i zjednoczenia zamyka w symbolu nocy, który dobrze wyraża sytuację duchową człowieka i sposób dążenia do Boga. Dla zrozumienia tej drogi należy niejako nałożyć na siebie dwa, osobno opisane procesy: oczyszczenia i zjednoczenia. Postępujące zjednoczenie sprawia coraz większe oczyszczenie miłości i odwrotnie. Nie sposób jednak zagłębiać się na tym miejscu w tę skomplikowaną problematykę ${ }^{24}$.

23 „Gdym dzisiaj, niezdolna nic wymyślić ani nic wiedząc od czego mam zacząć to pisanie, polecone mi przez posłuszeństwo, klęczała na modlitwie i błagała Pana, aby On raczył mówić za mnie, nasunęło mi się na myśl to, co zaraz opowiem" (TW I 1,1).

${ }^{24}$ Omówiłem ją szczegółowo w: J.W. Gogola, Św. Jan od Krzyża dzisiaj, s. 135 n. 
Można natomiast krótko przedstawić „małą drogę” św. Teresy z Lisieux, gdyż na tym polu znajdziemy największe zasługi najmłodszego doktora Kościoła ${ }^{25}$. Jakkolwiek patrząc od strony teologicznej, odkryła ona prawidłowość obecną także u św. Jana od Krzyża i św. Teresy z Ávili, dla niej było to olśnienie w jej doświadczeniu całkowicie nowe.

„Droga” na polu duchowości dotyczy procesu dokonującego się w czasie ziemskiego życia uświęcenia człowieka. Cały jego proces zmierza ku temu, by świętość Boga, otrzymana przez człowieka w sakramencie chrztu świętego, stała się świętością człowieka do tego stopnia, by go przemieniła zarówno wewnętrznie, jak i w całym sposobie jego bycia. Jakikolwiek przymiotnik czy inne wyrażenie postawione przy rzeczowniku "droga" dookreśla czy charakteryzuje sposób dochodzenia do chrześcijańskiej pełni. $Z$ takim założeniem należy wnikać w sens rozumienia „małej drogi”.

„Małą drogą” Teresa nazwała „swój sposób dążenia do Boga”, swoją duchowość ${ }^{26}$. Celem tej drogi jest świętość, pełnia miłości, zjednoczenie z Bogiem, chrześcijańska doskonałość.

Odkrycie to nie oznaczało kompromisu pomiędzy wzniosłym ideałem a nędzą człowieka. W takim wypadku byłaby to droga przeciętna, mierna, nie zaś mistyczna. Odkrycie polegało na znalezieniu rozwiązania zgodnego $\mathrm{z}$ naturą objawienia i prawami uświęcenia. Teresa odkryła rolę, jaka przypada w udziale Bogu i człowiekowi w procesie uświęcenia. Dzieło to przekracza

25 Por. tenże, Sekret św. Teresy z Lisieux. Elementy duchowości, Kraków 1999; tenże, Teologia komunii z Bogiem, wyd. 4, Kraków 2013, s. 146$-148$.

${ }^{26}$ Por. Teresa od Dzieciątka Jezus, Rady i Wspomnienia I, w: taż, Pisma, t. 2, autoryzowany przekład z francuskiego, Kraków 1971; S. Zalewski, Droga dziecięctwa duchowego według Teresy z Lisieux, w: W sercu Kościoła będę Miłościq̨. Materiały z ogólnopolskiego sympozjum... z okazji setnej rocznicy śmierci św. Teresy od Dzieciątka Jezus, Doktora Kościoła, KUL, 6 listopada 1997, red. M. Chmielewski, Ł. Kasperek, W. Słomka, Kraków 1998, s. 99-114. 
ludzkie siły, a zatem jego głównym autorem jest Stwórca. Od człowieka wymaga się odpowiedniej postawy i współpracy.

Teresa rozumie, że tylko Bóg może uświęcić człowieka. Ten powinien przyzwolić $\mathrm{Mu}$ na to uświęcenie. $\mathrm{W}$ dziele formacji duchowej ma być współpracownikiem Boga, który wyprowadza go z wszelkich duchowych kryzysów. Tutaj trzeba z cierpliwością znosić to, czego nie można zmienić własnymi siłami, nie zniechęcając się trudnościami. Albowiem rzeczywistość naszego spotkania z Bogiem wyznaczają z jednej strony nasza małość i ubóstwo, a z drugiej - miłosierdzie Boga.

W jaki sposób Teresa $\mathrm{z}$ Lisieux dokonała swojego odkrycia? ${ }^{27}$ Celem był wzniosły ideał świętości, o którym miała raczej wypaczone pojęcie, wynikłe $z$ błędnej formacji, w dużej mierze wywodzącej się z religijnego klimatu ówczesnej Francji, zaś punktem wyjścia brak możliwości osiągnięcia tego ideału. Chodziło więc o znalezienie jakiegoś pomostu pomiędzy tymi dwoma krańcami.

Punkt docelowy. Teresa pragnęła być wielką świętą ${ }^{28}$. Przyznaje również, że chcąc zrealizować to pragnienie, szukała wzorców wśród świętych kanonizowanych (por. Ms C, 2 v ${ }^{\circ}{ }^{29}$. Oprócz osobistego problemu świętości Teresę zajmowały też sprawy codzienne. Pełniła funkcję prowadzącej formację nowicjuszek, mimo że formalnie nie była mistrzynią. Tak więc do owego życiowego odkrycia przyczyniło się nie tylko zmaganie się z wielkim pragnieniem świętości, ale również z różnymi wewnętrznymi trudnościami oraz odpowiedzialnymi i delikatnymi zadaniami formacyjnymi, które przekraczały jej ludzkie siły.

27 Szczegółowo wyjaśniam tę kwestię w książce: J.W. Gogola, Sekret świętej Teresy z Lisieux, wyd. 2, Kraków 1999.

28 Św. Teresa od Dzieciątka Jezus, List XXXIII z 31 lipca 1888, w: taż, Pisma, t. 1, autoryzowany przekład $\mathrm{z}$ francuskiego pod kierunkiem O. Filka, Kraków 1971, s. 427.

29 Taż, Dzieje duszy (dalej: Ms; litery oznaczają manuskrypt A, B, C, po nich następuje numer folio, recto lub verso), w: taż, Pisma, t. 1. 
Punkt wyjścia. Była nim niemożność osiągnięcia celu przy aktualnym stanie jej wiedzy i doświadczenia. Być świętym to dla Teresy początkowo być podobnym do któregoś ze świętych kanonizowanych, jak to jednoznacznie wynika $z$ analizowanego poniżej tekstu. A porównanie siebie do któregokolwiek z nich nie jest pocieszające. Istnieje ogromna różnica pomiędzy znanymi świętymi a nią. Teresa wyciąga $\mathrm{z}$ tego porównania wniosek: taka świętość jest dla niej niemożliwa!

Odkrycie. Etapy odkrycia „małej drogi”, na które składa się kilka elementów, znajdziemy w Manuskrypcie C (por. Ms C, 2v$\left.-3 r^{\circ}\right)^{30}$. Są nimi: pragnienie świętości, niemożność osiągnięcia jej własnymi siłami, wewnętrzna pewność, że pragnienia pochodzą od Boga, odkrycie zobrazowane windą, potwierdzenie przez Pismo Święte ${ }^{31}$.

„Chciałabym znaleźć taką windę, która by mnie uniosła aż do Jezusa, bo jestem zbyt mała, by wstępować po stromych stopniach doskonałości" (Ms C, $2 \mathrm{v}^{\circ}-3 \mathrm{r}^{\circ}$ ). W przeciwieństwie do trudu wstępowania po schodach winda bez wysiłku ze strony człowieka wynosi go na określone piętro. To ona obrazuje właśnie „małą drogę", prostą i krótką. Można powiedzieć, że winda symbolizuje nie brak ludzkiego wysiłku (każdy przykład kuleje), ale potęgę łaski Bożej i właściwą postawę człowieka wobec Bożego działania. Cały trud ascetyczny zmierza ku temu, by powierzyć się Bożemu działaniu (chcieć wejść do windy i dać się wywieźć na boski poziom).

Teresa odkrywa teologiczną prawdę, że człowiek o własnych siłach nie jest w stanie osiągnąć całkowitego zjednoczenia z Bogiem. Znając zasady teologii mistyki, łatwo wyciągnąć wniosek, że „mała droga” Teresy jest drogą mistyczną w szerokim tego słowa znaczeniu, tzn. drogą, na której człowiek pozwala Bogu

${ }^{30}$ A. Combes, Introduzione alla spiritualità di S.Teresa del Bambino Gesù, Firenze 1949, s. 257.

31 C. De Meester, La dynamique de la confiance, wyd. 2, Paris 1995, s. 82. 
działać ${ }^{32}$. Znając definicję życia mistycznego, trudno nie zgodzić się z takim wnioskiem. Potwierdzenie swojego odkrycia święta z Lisieux znajduje w Piśmie Świętym, które zresztą także przyczyniło się do tego odkrycia. „Spodobało się Jezusowi wskazać mi jedyną drogę, która wiedzie w sam Boski żar; tą drogą jest zaufanie małego dziecka, które bez obawy zasypia w ramionach swego Ojca... «Jeśli kto jest maluczki, niech przyjdzie do mnie» (Prz 9,4), rzekł Duch Święty przez usta Salomona i ten sam Duch miłości powiedział jeszcze «Mali otrzymują miłosierdzie» (Mdr 6,6)" (Ms B, 1 ro).

Odkrywając małą drogę, Teresa wkrótce potem odkryje także tajemnicę Bożego Miłosierdzia. Miłosierdzie to Miłość Boga pochylająca się nad ubóstwem człowieka (por. Ms B, 3 vo). Jest to na wskroś ewangeliczna definicja.

Teresa znalazła drogę, na której świętość Boga staje się świętością człowieka. Odkryła drogę do wielkości na miarę Boga. Powie o niej na łożu śmierci, że „polega na usposobieniu serca, które sprawia, że jesteśmy małymi i pokornymi w objęciach Boga, uznającymi swą słabość i ufającymi do zuchwalstwa Jego dobroci ojcowskiej” (NV, 3 sierpnia) ${ }^{33}$. Iść małą drogą „to uznawać swoją nicość, oczekiwać wszystkiego od Boga, jak małe dziecię oczekuje wszystkiego od ojca, niczym się nie kłopotać, nie gromadzić mienia" (NV, 6 sierpnia).

„Mała droga" nie polega tylko na uznaniu własnej małości względem Boga, jak i też na uznaniu nieograniczonej Miłości Miłosiernej Boga, zdolnej zaspokoić wszystkie pragnienia człowieka. Takie jej pojmowanie łatwo prowadzi do fałszywej mistyki. „Mała droga” jest „iskrą nadziei”, która przeskakuje z ogromnych

32 Por. opracowanie pod takim właśnie tytułem: J.W. Gogola, Mistyka Teresy z Lisieux, w: tenże, Mistyka Karmelu, wyd. 2, Kraków 2017, s. $123-$ -142 .

${ }^{33}$ Św. Teresa od Dzieciątka Jezus, Novissima verba (dalej: NV), w: taż, Pisma, t. 2, s. 486. Jest to jej zdaniem określenie świętości, ale wiadomo, że chodzi o dyspozycję do świętości. 
aspiracji ludzkiego „nic” na Boga, który pragnie napełniać owo ludzkie ubóstwo swoim bogactwem: „aby Miłość była w pełni zaspokojona, musi się zniżyć, zniżyć aż do głębin nicości i tę nicość przemienić w ogień" $\left(\mathrm{Ms} \mathrm{B}, 3 \mathrm{v}^{\circ}\right)^{34}$.

"Mała droga” bywa też nazywana „drogą dziecięctwa duchowego", aczkolwiek nazwa ta nigdy nie wyszła z ust samej Teresy. Jednak nie jest to błąd. Nazwała ją tak matka Agnieszka, rodzona siostra świętej. Postawa dziecięca wobec Boga nie jest etapem w życiu duchowym, który pewnego dnia pozostawia się za sobą. Jest to sposób bycia i postępowania zawsze konieczny do wzrastania w łasce. Teresa odkryła tę prawidłowość rozwoju, przebywając długą drogę. Jej przykład pokazuje, że wszystko jest możliwe, gdy człowiek polega nie na swojej słabości, lecz na mocy Boga.

Doktorzy Karmelu doskonale znają objawioną i nauczaną przez Kościół prawdę o człowieku. Potwierdzają jego wielką godność i piękno, ale przede wszystkim ukazują drogę, która prowadzi do pełnej realizacji człowieka według Bożego zamysłu. Człowiek nie rodzi się doskonały, dlatego że jego najgłębsza natura jest duchowa. Żeby osiągnąć pełne zjednoczenie z Bogiem, a tym samym jedność z sobą i całym stworzeniem, musi przebyć długi proces wewnętrznej przemiany, posiadający dwa aspekty, stosownie do dwóch aspektów Misterium Chrystusa, w które każdy wierzący zostaje zanurzony przez chrzest święty: śmierci i zmartwychwstania, światła i ciemności. Pozostają one w nieustannej korelacji, jakkolwiek w dziełach naszych doktorów omawiane są oddzielnie. Przed czytelnikiem stoi więc trudne zadanie formacji teologicznej i konfrontacji ich nauczania $\mathrm{z}$ własnym życiem duchowym.

${ }^{34}$ Por. R. Laurentin, Iniziazione alla vera Teresa di Lisieux, tłum. $\mathrm{z}$ francuskiego, Brescia 1972, s. 103. 


\section{La persona umana nell'esperienza spirituale dei mistici del Carmelo}

Il teologo spirituale si occupa della persona umana dal punto di vista della sua vocazione alla santità. La fonte della nostra ricerca sono le opere spirituali dei tre grandi santi carmelitani, Dottori della Chiesa: Teresa di Avila, Giovanni della Croce e Teresa di Lisieux. Loro conoscono molto bene la dignità della persona umana rivelata e proclamata dalla Chiesa. Confermano pertanto la bellezza dell'uomo nello stato di grazia, ma soproatutto ci mostrano l'itinerario spirituale che conduce all'unione con Dio - fonte della santità umana. Per cui la struttura fondamentale di questa espisizione riguarda la situazione dell'uomo all'inizio del suo cammino spirituale - uomo imperfetto: amore egoistico, distratto a molti oggetti, poca libertà e altrettanto poca conoscenza di Dio e di sé stesso; alla fine del cammino uomo perfetto: capace di realizare il primo commandamento di amare Dio con tutto sé stesso, libertà spirituale, integrazione della persona, operazione "al modo divino", partecipazione alla Saggezza di Dio; e infine uomo in cammino dove si vedono i suoi sforzi di corrispondere alla pienezza della sua vocazione. Grazie alla dottrina spirituale dei Dottori carmelitani possiamo capire meglio la dinamica del cammino spirituale e perfino introdurre alcuni modificazioni alle proposte dei manuali di spiritualità. La via al unione con Dio è nello stesso tempo un processo molto complesso che consta di due aspetti fondamentali corrispondenti ai due aspetti del Mistero di Cristo in cui partecipa ogni credente - morte e risurrezione, tenebre e luce. Da notare però, che l'esperienza della presenza di Dio e dell'operazione della sua grazia diventano la fonte del processo in cui tutti gli singoli elementi ed aspetti sono strettamente legati a sé e condizionati vicendevolmente. 